\title{
UNIVERSITY-INDUSTRY COLLABORATION IMPORTANCE IN INNOVATIVE BRAZILIAN INDUSTRIAL FIRMS: A SECTORIAL MODEL ${ }^{\circ}$
}

\author{
IMPORTANCIA DE LA COLABORACIÓN UNIVERSIDAD-EMPRESA EN EMPRE- \\ SAS INDUSTRIALES BRASILEÑAS INNOVADORAS: UN MODELO SECTORIAL
}

\author{
Ronivaldo Steingraber* \\ Flávio de Oliveira Gonçalves**
}

enviado: 1 marzo 2017 - aceptado: 4 julio 2017

\begin{abstract}
This article examines empirically the university-industry collaboration (UIC) importance in innovative firms on Brazilian industry. This relation is considered an important tool for economic growth in innovation-led firms. It was used a hierarchical regression model for 25.667 innovative industrial firms in the year 2005, the innovation involves product, process, or organizational change. The Total Factor Productivity was introduced as independent variable, because it can be used in all firms as performance measure, and it was average centralized. The TFP is explained by firm's internal capabilities, and in industry by the UIC importance. The found results are upward average (positive sign), and downward average (negative sign). The sectorial impact of UIC in the TFP is positive, but near zero. The internal capabilities present exchanged signs between the firm and the industry, only innovative labor have both signs positive. The random effects identify nine industries with upward productivity gains, 8,26 \% of total Brazilian industry, and these industries are traditional, low-tech intensity, only the automotive industry is medium-technology. Twenty industries have downward productivity gains, 18,35 \% of total Brazilian industry, and between them are high-technology industries, as diverse capital tools, and electronics.
\end{abstract}

* Universidade Federal de Santa Catarina. Correo electrónico: ronivaldo.steingraber@gmail.com

** Universidade Federal do Paraná. Correo electrónico: f.goncalves@ufpr.br

- Steingraber, R., \& de Oliveira Gonçalves, F. (2017). University-industry collaboration importance in innovative Brazilian industrial firms: a sectorial model. Estudios económicos, 34 (69), 25-45. 
JEL Code: L60, O31, O33.

Key words: University-industry collaboration; Innovation; Brazilian Industry; Productivity.

\section{Resumen}

Este artículo examina empíricamente la importancia de la colaboración universidad-industria (CUI) en empresas innovadoras en la industria brasileña. Esta relación se considera una herramienta importante para el crecimiento económico en las empresas innovadoras. Se utilizó un modelo de regresión jerárquica para 25.667 empresas industriales innovadoras en el año 2005, la innovación abarca producto, proceso, o cambio organizacional. La Productividad Total de Factores (PTF) se introdujo como variable independiente, ya que puede ser utilizada en todas las empresas como medida de desempeño, y se centró en la media. La PTF se explica por las capacidades internas de la empresa, y en la industria por la importancia de la CUI. Los resultados encontrados son media ascendente (signo positivo) y media descendente (signo negativo). El impacto sectorial de la CUI en la PTF es positivo, pero tiende a cero. Las capacidades internas presentan signos intercambiados entre la empresa y la industria, sólo la mano de obra innovadora tiene ambos signos positivos. Los efectos aleatorios identifican nueve industrias con aumentos de productividad, 8,26 \% del total de la industria brasileña, y estas industrias son tradicionales, de baja intensidad tecnológica, solo la industria automotriz es de tecnología media. Veinte industrias tienen aumentos de productividad por debajo de la media, 18,35 \% del total de la industria brasileña, y entre ellos son industrias de alta tecnología, como diversas herramientas de capital y electrónica.

Código JEL: L60, O31, O33.

Palabras clave: colaboración universidad-empresa; innovación; industria brasileña; productividad.

\section{INTRODUCTION}

This article examines empirically the importance of university-industry collaboration in Brazilian industry. In Schumpeterian Literature, this relationship involves Social Capital formation, and considers all relations between companies and institutions (universities p. ex.) with the aim of innovation development. This relation is considered an important channel for innovation, and connects the tech- 
nological knowledge generation from the university into the potential of generate economic value in industry by innovative products, process and practices.

This relation is highlighted by theories of innovation, as complement of institutions in systemic innovation process. In this sense, firms do not have all the innovative capabilities demanded, and it is necessary to search these resources to promote the innovation process. By university side of relation, the capabilities are engaged in research and development of knowledge, but are not always dedicated in developing new products and services.

This article estimates a multilevel regression model of social capital between innovative firms and universities in Brazil in the year 2005. The estimated results contribute with the applied literature on Economy of Innovation. Innovative companies do more importance in relation of university. The formation of social capital includes the formation of partnerships and strategies, the variable used belongs to the PINTEC ${ }^{1}$ database and identifies the degree of university importance, as other institutions, as analysis laboratories and public research institutes that carry out tests, analyzes and tests of products and processes directed to technology transfer and innovation into industrial companies.

The data used encompass industrial companies that innovated in the year 2005. It is considered all the industrial companies with more than ten employees. The population totals 91.000 companies, inside the sample of population of 25.667 innovative companies, which answered the question about the importance of university, and other research and development institutes to the innovative company ${ }^{2}$. The database belongs to Instituto Brasileiro de Geografia e Estatística (IBGE), and Instituto de Pesquisa Econômica Aplicada (IPEA) ${ }^{3}$. All are microdata whose observation is the company. The complete list of variables is present in annex.

The hypothesis estimated in this article establishes that innovating companies attribute more importance to university and other institutes of research and technological development, and have more relevance in their internal and external capabilities, and they are more productive. The dynamic capabilities to innovate

\footnotetext{
1 PINTEC is the Innovative and Technology Research for Brazilian industrial enterprises.

2 The question enables answers between zero and five.

3 It was used variables from different industrial statistics, as Pesquisa Industrial Anual (PIA), Pesquisa Industrial de Inovação Tecnológica (PINTEC), Relação Anual de Informações Sociais (RAIS), foreign trade data from SECEX (Secretaria de Comércio Exterior), and patent data from Instituto Nacional de Propriedade Industrial (INPI)
} 
are introduced by the study of Teece et al. (1997) that introduces the relation between skills and competences to innovative, and the development of innovations inside the firm. These capabilities depend of external environment in which the company belongs, and in the Schumpeterian Literature they are in the industry (Sector System of Innovation), in the territory (Regional System of Innovation), and in the country (National System of Innovation).

This paper used the limits of Sector System of Innovation to establish the external variables to the econometric model, p. ex., access to foreign commerce, market share). The question tested in this paper is if there are differences in the importance of universities, and others knowledge institutions, inside the group of innovative companies. The hypothesis is that there are a positive relationship between importance of university, productivity, and internal capabilities in the innovative company. The contribution of this paper is the control of importance of universities, and other knowledge institutions in the industry into productivity of innovative companies. The use of productivity as dependent variable is justified by their generality, and applicability in all sector of industry.

The empirical relation between university importance and capabilities to innovate was verified in Brazilian industry (Negri, 2006), the results found were positive, as in this study. The contribution of this paper resides on verification of university importance to innovate controlled by industrial sectors, impacting the capabilities of innovative company, and their productivity.

The structure of paper is as follows. Section Two presents the theoretical and empirical relationship between the university, and other centers of development and research, and the innovation in companies. Section Three presents the model to be estimated, it explains the companies' productivity as function of internal and external dynamic capabilities through a model of multilevel regression to Brazilian industrial companies. The estimated data show $1 / 4$ of industrial sectors present productivity gains different of average industry productivity. The results confirm the hypothesis of technological different among the economic sectors. The Sector System of Innovation establishes variant technological opportunities to sectors, and the university importance and their impact over productivity, and internal capabilities vary from sector to sector. Section Four concludes the paper. 


\section{THE IMPORTANCE OF UNIVERSITY IN INNOVATION PROCESS}

The innovation process is analyzed in the Schumpeterian theory as a systemic process. Innovation is not an isolated act of company, and it arises from the connection with the institutional environment, creating social capital (Nelson \& Nelson, 2002). The company needs to develop skills and competencies to innovate, and all these features are called capabilities, and they are the basis of development, and search for technological knowledge in innovative company (Teece et al., 1997).

The innovation is systemic because its linking with a social network, involving the generation, dissemination, and use of technological knowledge. The company operates in this innovation network, with various private and social actors with different interests, and different competences and knowledge (Nelson \& Nelson, 2002).

Regarding the role of institutions in technological knowledge development, it is possible to confirm the central emphasis on the importance of universities in the generation, use, and distributions of technology knowledge, as well as in training and consulting. In addition, it has applied services to innovation, such as laboratories tests, reports, and various solutions to innovation development in private sector (Nelson \& Rosenberg 1993).

One of contributing factors of universities to technological advance is the human capital development. However, university's research is an important factor of technological progress in society, clustering innovation, new ideas, and solutions around itself (Audretsch et al. 2005). The formation of technological entrepreneurship is higher around universities. The regional innovation system is developed with strong participation of universities (Cooke et al., 1997). The sectoral system of innovation has the university as one of the most important institutions into innovation process (Malerba, 2002). Other systems of innovation, as national system of innovation (Andersen and Lundvall, 1997), and technological system (Carlsson and Jacobson, 1997) identified the university as a central institution in innovation process too.

It is noticed that the innovation system show the relation between companies (with their capabilities) and institutions, like a bridge into innovation process linking market and society. In other words, the knowledge generation is a social work, involving companies, and institutions, as universities, centers of development, consulting and technological services, public laboratories, etc. 
Universities, public laboratories and research and development institutes are important knowledge construction institutions. They have a central role at expansion of innovative capabilities, and all size of companies, including entrepreneurship, can benefit from the knowledge generated in them (Etzkowitz, 1998).

But how this knowledge impacts the innovation in the companies? The knowledge development in institutions are central in innovation process, but the innovative company must have the capabilities required to perform the knowledge capture, besides, the innovation can be developed in the company, as the research process (Colombo \& Delmastro, 2002).

First the institutions of knowledge productions, with great emphasis at the university, dominate the construction of rules of production, use, and regulation of technology (Schot \& Geels, 2007). They offer technical services, used to the development of new products and services in innovative companies (Godin \& Gingras, 2002).

The relevant institutional environment to relation between universities and firms also demand a framework that facilitates the innovation process. First, property rights as essential to guarantee the success of transformation of knowledge into new products and services (Colyvas et al., 2002; Panagopoulos, 2003). Other important channel of interaction between knowledge institutions and companies is the presence of Innovation Offices, specialized in offer the knowledge and solutions from universities to interest companies in innovation. By side of market, there are consulting, training, and others specialized companies in develop innovative solutions, assist on contracts formulation, open partnership, and find new opportunities, including finance services and market prospect.

It is possible to perceive the linking among market (companies and innovative services) and institutions (universities, public laboratories, and development and research centers). These linking can generate value, and the literature called it of Social Capital. This is reason why Nelson and Nelson (2002) call the technological knowledge, when it becomes the basic input for innovation, as a "social technology", because it is developed only when a connection is formed by social and economic actors. The relation between university, industry and other social actors to development of technological expertise is denominate of social capital formation to innovation ${ }^{4}$.

4 See Putnam (2001), Coleman (1988), and Knack and Keefer (1997) to the definition of social capital, and Nelson and Sampat (2001) to importance of social capital in economic process of innovation. 
Empirically the university-industry collaboration is a research object in various studies, and its conclusions identify several mechanisms of technology transfer between the two sides of relation. The university is specialized in develop and transfer technology knowledge, as to train the corporate researchers in epistemological thinking process (Motoyama, 2014).

The company develops routines and internal capabilities to capture and use the knowledge from institutions. The knowledge transfer may occur by formal and informal channels (Azagra-Caro et al., 2017), and it results of collaborative development and research between firms and universities (Scandura, 2016), establishing alliances to share costs (Anatan, 2015), and funded contracts to finance these costs (Fernandes et al., 2016), such contracts define property rights, and the division of joint R\&D (Fuentes \& Dutrénit, 2012), as the commercialization form of innovation (Plewa et al., 2013).

The collaborative knowledge between the university-industry leads more patents in fields of measurement and chemistry, led by research in United States and Japan (Chang, 2017), it is visible the constrain of researcher's disciplinary filiation at university directing the application of knowledge (Franco \& Haase, 2015). Other limit in university-industry relation is verified on Technology Transfer Office (TTO) presence, besides the university localization, both enhance the relationship's success (Bergebal-Mirabent et al., 2015). The university localization may restrict the knowledge transfer in some industries, but for biopharmaceutical industry this restriction is less, certainly, because it is a global industry (Malik, 2013).

When the technological profile is considered, the high technologies are not the central focus of collaboration. Low-tech industries can benefit of collaborative R\&D too (Maietta, 2015), as new emergent and mature industries (Freitas et al., 2013).

The university-industry collaboration is perceived in developed and developing countries. Specifically, in Brazil, there are barriers in the progress of this relationship. It is perceived limits of technology in industrial sectors, more the university limits in interaction with private sector (Lemos \& Cario, 2017).

The hypothesis that university is an important factor for absorption of knowledge in the Brazilian industrial firms is tested on study of Negri (2006). The author shows that the most innovative Brazilian industrial firms have specific capabilities, as human capital and the formation of partnerships with universities to innovate. 
In resume, the literature, the most innovative companies have more internal capabilities, as more human capital, they pay higher wages, and are more productive, besides having access to foreign trade, and the university importance, as other institutions of research and development, is higher than non-innovative companies. The hypothesis that this relation varies among industries is tested on next section.

\section{THE MODEL}

The presence of universities is crucial in the process of firm's innovation. The model examines empirically the total factor productivity (TFP) in the Brazilian industrial firms in year 2005, according to the firm's capabilities, and the importance degree of cooperation with universities, research centers and tests laboratories.

The estimation is performed by a hierarchical regression model. See Bryk and Raudenbush (2002) for the analysis of multilevel regression models. The use of this regression methodology is justified by division of behavior in groups, which can be hierarchized in groups, or levels. The group average (superior level) influences the individual average (first level).

We estimated the model by Maximum Likelihood (ML) methodology, because the OLS, as others estimation methods, is not consistent (Bryk \& Raudenbush, 2002). The equation of the first level that explains the company's TFP by their innovative capabilities can be defined as (Steingraber, 2009) ${ }^{5}$ :

$$
T F P_{i j}=\alpha_{0}+\alpha_{1} I C_{i j}+e_{i j}(1)
$$

Where equation (1) shows the $T F P_{i j}$ (Total Factor Productivity) of firm $i$ in sector $j$ estimated by a linear coefficient $\left(\alpha_{0}\right)$, and a vector with the internal dynamic capabilities $\left(\boldsymbol{I} \boldsymbol{C}_{i j}\right)$, and the noise $\left(e_{i j}\right)$. The internal dynamic capabilities is compost of nine variables: percentage of workers with third-degree, average worker income, average schooling time of workers, innovative labor, number of

5 The original model develop in the Doctoral Thesis was building with a research project at the Instituto de Pesquisa Econômica Aplicada (IPEA) - Applied Economic Research Institute - and Observatório da Inovação (USP) — Innovation Observer (São Paulo University) — with the micro data from IBGE. The estimated model and its theoretical discussion, and discursive statistics (that show productivity differences between firms and industries at the first level, justifying the use of hierarchical estimation) are not showed in this paper. 
patents requests, market share, number of workers by job contracts, export value, and the import value. The variables meaning is presented in the annex A.

The TFP is calculated by the residue of Abramovitz (1954), as suggest Antonelli (2003). It is calculated as difference in change rate of product value, less the amount spent in factors, now seen as the change rate in spending on labor and investment (change in capital stock of company), and does not as a marginal rate as Solow. The determination of TFP is given as:

$$
T F P=d Y-\left(\frac{d y}{d k}\right) d K-\left(\frac{d y}{d l}\right) d L
$$

Where $d Y$ is the change in product (net sales). The derivative $\left(\frac{d y}{d k}\right)$ and $\left(\frac{d y}{d l}\right)$ are respectively the output elasticity of capital and labor. Since $d K$ and $d L$ indicate the change in capital (investment) and labor. The estimation of equation (2) was conducted to year 2005 regarding 2004, as a change rate, and is not in logarithms, as a Cobb-Douglas function. Thus, the partial derivatives do not represent the marginal contribution of capital and labor in product, but rather, they represent the relative share of capital and labor in the product, finally, the variation of capital is calculated as investment, facilitating the determination of the statistical variable, since the PIA does not have a variable computing the value of capital shares in Brazilian industry. The change in capital (investment) was calculated as the amount spent by company in acquisition of assets (machinery, buildings, equipment and other fixed assets in PIA), less the low value of these assets. The variation in work shows the change in the spending on payroll (salaries, wages, benefits, Social Security and other computed values in the category of wage bill of PIA).

The second hierarchy of equation considers the university-industry collaboration importance of universities, test and research centers 6 into firms that innovated in year $2005\left(U_{j}\right)$. This variable is sectoral (industry), and the hypothesis is that industries with more importance at university-industry collaboration present firms with higher TFP (as internal capabilities too). If this hypothesis is correct, there is evidence of importance of Sectoral Innovation System (Malerba, 2002) in the Brazilian innovative firms, because the knowledge transfer is oriented by the sectoral trajectory of technology. The second model equation is:

$$
\alpha_{1}=\beta_{j}+r_{j}
$$

$6 \quad$ It is a dummy variable with value 1 if firm answer in the fields 1 and 2 (high and medium) in the PINTEC's questions 115-117, and 0 if the answer is 3 or 4 (small or not relevant) in the same questions. 
The equation (3) show that the TFP's elasticity of firm $i$ in industry $j$ can be explain by fixed effect of sector $\left(\beta_{0 j}\right)$, and a random effect of sector $\left(r_{i j}\right)$. Introducing the sectoral variable Importance of university-industry collaboration stays as:

$$
\alpha_{1}=\delta_{j}+U_{j}+r_{j}
$$

Where $\delta_{j}$ is the average TFP of industry, the university-industry importance is $U_{j}$, and $r_{j}$ is the white noise of sector in firm. The second part of equation (3) is the random effect of industry that explains the TFP of firm, and it captures the difference of TFP among industries.

Introducing (4) in (1) we have:

$$
T F P_{i j}=\alpha_{0}+\left(\delta_{j}+U_{j}+r_{j}\right)\left(I C_{i j}\right)+e_{i j}
$$

Rearranging the equation (5) it stays:

$$
T F P_{i j}=\alpha_{0}+\delta_{j} \boldsymbol{I} \boldsymbol{C}_{i j}+U_{j} \boldsymbol{I} \boldsymbol{C}_{i j}+r_{j} \boldsymbol{I} \boldsymbol{C}_{i j}+e_{i j}
$$

The estimative were conduct in equation (6), and it presents the TFP of firm $i$ in industry $j$ is dependent of an intercept $\alpha_{0}$, and the white noise $e_{i j}$. The model nucleus is compound of three parts: i) the fixe effect of TFP of industry $j$ in the internal capabilities of firm $\left(\delta_{j} \boldsymbol{I} \boldsymbol{C}_{i j}\right)$, ii) the fixed effect of the university-industry collaboration of industry $j$ in the internal capabilities of firm, and iii) the random effect of industry in the internal capabilities.

The hierarchical regression has variables with centralized average. Their interpretation is particular; the sign positive shows that variable is contributing with the firm's TFP above the industry average. Just the sign negative shows that the variable is contributing less in the firm then in the industry. The results of estimated equation (6) are presented and analyzed in the next section.

\section{RESULTS}

The estimated fixed and random effects of equation (6) show the TFP of innovative firms depending of internal capabilities of firm, and the importance of university-industry collaboration. The result for fixed effects is presented in Table 1. The random effects are presented in table 2 below. 
All estimative were realized with the variable introducing. Variables with high correlation reduced the model robustness, and were taken from estimates ${ }^{7}$. The variables of schooling and income of workers have high correlation in firm, but do not in industry, and were kept in estimation.

TABLE 1: firm's TFP explained by internal capabilities and university-industry collaboration in year 2005

\begin{tabular}{|c|c|c|}
\hline VARIABLE & $\alpha(\mathrm{t})$ & $\rho$ \\
\hline Intercept & $\begin{array}{r}-5256034 \\
(-4.31)\end{array}$ & $* * *$ \\
\hline Graduate and undergraduate workers & $\begin{array}{l}-133341 \\
(-20.76)\end{array}$ & $* * *$ \\
\hline worker's average income & $\begin{array}{r}10014 \\
(12.08)\end{array}$ & $* * *$ \\
\hline worker's average study & Ns & \\
\hline innovative labor & $\begin{array}{l}419647 \\
(13.55)\end{array}$ & $* * *$ \\
\hline Patents & $\begin{array}{r}442094 \\
(6.17)\end{array}$ & $* * *$ \\
\hline Share & $\begin{array}{r}1.04 \mathrm{E}+13 \\
(24.86)\end{array}$ & $* * *$ \\
\hline number of employers & Ns & \\
\hline export value & $\begin{array}{l}-0.7814 \\
(-46.37)\end{array}$ & $* * *$ \\
\hline import value & $\begin{array}{r}-0.3374 \\
(-8.67)\end{array}$ & $* * *$ \\
\hline University & $\begin{array}{r}2.01 \mathrm{E}+12 \\
(3.80)\end{array}$ & $* *$ \\
\hline graduate and undergraduate workers * UIC & NS & \\
\hline worker's average income * UIC & $\begin{array}{c}-196398 \\
(-17.97)\end{array}$ & $* * *$ \\
\hline worker's average study * UIC & $\begin{array}{r}21314413 \\
(5.25)\end{array}$ & $* * *$ \\
\hline
\end{tabular}

7 The variables schooling and income of employees exemplify the situation. The worker's schooling (average study) is significant only in industry, and does not in firm. Other variables, as capital turnover, and international input access were taken of estimative, because were autocorrelated. 
innovative labor * UIC

Patents * UIC

Share * UIC

number of employers * UIC

export value * UIC

import value * UIC

Source: Data calculated by the author with micro data from the IBGE based on equation (6). $* * * p<0.001, * * 0001<\rho<0.05 ; * 0.005<\rho<0.1$

$t$ statistic in parenthesis

The data in Table 1 show that Brazilian industrial firms show productivity gains with the innovative labor, patents and the labor's income. The increased firm's market power (share) is almost zero, but also positive. Other variables that showed minor contribution on productivity (negative sign) are exports, imports and labor force with third degree. Schooling time and number of employees (contracts) were not statistically significant in explaining the company’s productivity.

With UIC controlling in industry, the variables with productivity gains below average are: labor income, patents and the participation of firms at market. Schooling, innovative labor, number of workers and foreign trade (exports and imports) contributes to productivity gains more than average in industries.

Some differences between firm and industry can be identified in estimated results of university-industry collaboration in innovative firms.

The first difference is the role of foreign trade. In firms, exports and imports have an impact below the average (negative sign), already in industry the impact is positive in the presence of universities (above average). Thus, differences in foreign trade are more visible among the economic sectors. Studies such as Negri and Salerno (2005) and Negri and Araujo (2007) show that impact of foreign trade 
is positive in innovative Brazilian industrial firms, however, the results here show the estimated impact of foreign trade explaining less the productivity of individual firms and more gains of productivity in industry, where industries with more cooperation with universities have more impact of foreign trade in productivity.

The second difference is in labor income, number of patents and the market participation of firms. These variables generate productivity gains above average in firms, and contribute to productivity below industry average. In this sense, we find that these variables are more important intra-firm, than in industry to explain productivity gains. Higher wages working in firms is a strategy to attract better human capital that generates improved productivity, the relation between industries and universities is not dominated by sectors with higher incomes, which shows that orientation of university does not follow the same business logic, as commercial orientation. The patents show the development of firm's factors for innovation in the form of property rights that can be transformed into future innovations, and productivity gains, in industries with more university-industry collaboration importance, are not more generation of patents. The Share shows that firms with market power experience have more productivity gains; however, the importance of university-industry in this relation is not so important.

The third difference is the firm size. For firms, the size was not statistically significant in explaining productivity gains; however, in industry the importance of university is positively related to firm size. Thus, industries with larger firms tend to have higher probability of productivity gains with the university approximation to generate innovations. Another explanation lies in presence of fixed costs of training, infrastructure, and availability of skilled labor to firms interact with the university, creating social capital and benefiting itself from the collaboration, these factors are present in industry (localized knowledge spillovers). This result shows the limit of knowledge spillover in Brazilian university-industry collaboration, where the firm size in industry determines the relation dynamics with university, as Bercovitz and Feldman (2006) appointed. The economic literature of technological complexity, and Sectoral Systems of Innovation explain the limitation of spillovers between industries ${ }^{8}$, however, the results show that this limit can also be dependent of capabilities and structure between firms and universities, where mature industries with larger firms establish greater links with universities. Moreover, new sectors have not great productivity gains with the universityindustry collaboration as mature, and low-tech, industries.

8 This explains why the technological trajectory belongs to the industry. 
There are not only differences perceived between firms and industry. Human capital has positive impacts on the firm (innovative labor) and industry (education and innovative labor). The negative highlight was the variable participation of labor with third grade with below-average value in firm and not significant in industry. This shows that the firms with high rates of labor with schooling do not develop a sufficient condition to generate productivity gains, for this, human capital should be instructed to be innovative.

Considering the random effects in the industry, Table 2 shows the significant industries. The industrial classification used is the CNAE 1.0 with 109 sectors 9 .

TABLE 2: random effects estimate

\begin{tabular}{lcc}
\multicolumn{1}{c}{ Industry } & UIC & $\rho<0$ \\
\hline Extraction of coal & + & $* * *$ \\
Service related to the extraction of oil and natural gas & + & $* *$ \\
Extraction of iron ore & - & $* *$ \\
Extraction of stone, sand and clay & - & $* *$ \\
$\begin{array}{l}\text { Processing, preservation and canning of fruits, vegetables and } \\
\text { other vegetables } \\
\text { Manufacture of sugar refining }\end{array}$ & - & $* *$ \\
Manufacture of beverages & + & $* *$ \\
Manufacture of tobacco & - & $* *$ \\
Shoemaking & + & $* *$ \\
Manufacture of wood, cork and twisted material & + & $* *$ \\
Manufacture of petroleum products
\end{tabular}

9 Classificação Nacional de Atividades Econômicas or National Classification of Eaconomic Activities. 
Manufacture of inorganic chemicals

Manufacture of pharmaceuticals

Manufacture of pesticides

Manufacture of soap and detergents, cleaning products and toiletries

Manufacture of rubber

Foundry

Manufacture of motors, pumps, compressors and transmission equipment

Manufacture of tractors and machinery and equipment for agriculture, poultry and livestock products

Manufacture of machinery and equipment for use in mining and construction

Manufacture of machinery and equipment, electronic systems for data processing

Manufacture of electrical equipment for vehicles

Manufacture of basic electronic

Manufacture of equipment and telephony equipment and radio and television transmitters and radio

Maintenance and repair of equipment and telephony equipment and radio and television transmitters and radio

Manufacture of cars, vans and utilities

Construction, assembly and repair of aircraft

Manufacture of miscellaneous products

Significant sectors

Positive

Negative

Source: The author with micro-data from the IBGE based on equation (6).

*** $\mathrm{P}<0.001$, ** $0001<\rho<0.05$; * 00:05 $<\rho<0.1$ 
The data in Table 2 show that 29 sectors are statistically significant with presence of university-industry collaboration determining firm's TFP different of average productivity of industry, which represents $26.60 \%$ of Brazilian industrial sector. Thus, the remaining $73.40 \%$ of Brazilian industries have increased productivity of their firms in the average.

The average deviation can be clustering into two groups: i) sign positive: average upward productivity industries, and ii) sign negative: average downward productivity industries. Positive sign industry totaling nine, since industries with negative sign totaling twenty, these represents respectively $8.26 \%$ and $18.35 \%$ of Brazilian industries.

The average upward productivity industries with respect of university-industry collaboration are: extraction of coal; oil and minerals (iron); manufacture of tobacco products; wood products; recorded materials; inorganic chemicals; machinery and equipment for the construction industry; and the automotive industry. All these industries are low-technology intensity, and the automotive industry is medium-high-technology.

The average downward productivity industries are: extraction of stone, sand and clay; preserved food production; refining sugar; beverages; footwear; petroleum; pharmaceuticals; agrochemicals; products of cleaning; rubber; foundry; various manufactures of capital tools and machinery (motors, tractors); various manufactures of electronics equipment, electrical materials (for vehicles) and electronics; telephony equipment; miscellaneous items; and aerospace industry. Between these industries there are low-technology sectors, but there are intensive technology industries, as electronics, and aerospace industry.

These estimate results show a timid and weak importance of university in knowledge partnership with industries, major the high technology industries. This result shows that the idea of technologically advanced industries is not well adapted to Brazilian reality, such as the Pavitt's taxonomy (Pavitt, 1984; Dosi, Pavitt \& Soete 1990), because the productivity's gains are associated to firm's capabilities more than the university's importance at industry.

This result shows us that Brazilian industry is commodity-led, and not innovative-led. It is necessary to develop public policies to growth-up innovations from university-industry collaboration in Brazil. For decades, the industrial policy was restricted in open the domestic market, with objective of prices controlling, and consume increasing. Nowadays, all efforts were concentrated in petroleum industry. 
The limit of this research resides in one-year analysis, from the cross-section regression. The productivity growth is reflex of more time. Besides, there is not an explicit definition of national strategic industries, and public policies of university-industry collaboration to then. The paper contribution resides on verification of university-industry collaboration inside the industries, and their impact in productivity gains, and internal capabilities of industrial firms in Brazil. These empirical results contribute with the literature of Sector Innovation System, because identify sectoral limits in the importance of university knowledge transfer.

\section{CONCLUSION}

This article considered the impact of university-industry collaboration into systemic innovation process. In this sense, the model estimated the firm's productivity according to their capabilities to innovate, and importance of universityindustry collaboration in innovative firms.

The estimated results show differences between innovative capabilities in firms, and the importance of university-industry collaboration in promoting productivity gains. These differences indicate an important contribution of size of business, and trade in industries with more university importance. The income, patents and market concentration were important in explain the productivity gains inside the firms.

Between the industries with productivity gains, there are not high technology sectors. Only mature industries, with low-intense technology present productivity gains average upward.

This paper found evidences that Brazilian industry has not been orient by traditional technology classification. Where was expected that high-intensive technology industries would present more productivity gains.

This result reinforces the idea that university-industry collaboration in Brazil is still incipient and weak, and needs to walk a long way to assert itself as an instrument to support innovation.

We encouraged future studies in researches the institutional environment dedicated for university-industry collaboration, such as offices of innovation, and technology and patents transfer. Finally, the role of government, not verified in this study, may be an important success factor of this relation, and the missing link in development of innovation in Brazilian industry. 


\section{ANEXX A}

Table A1: variables meaning

\begin{tabular}{|c|c|c|}
\hline Variable & Base & Construction \\
\hline $\begin{array}{l}\text { percentage of workers } \\
\text { with third level }\end{array}$ & RAIS a & $\frac{\text { graduated workers }}{\text { total of workers }}$ \\
\hline $\begin{array}{l}\text { Average income of } \\
\text { workers }\end{array}$ & RAIS a & $\begin{array}{l}\text { average wage in Reais (R\$): } \\
\frac{\text { total of wages }}{\text { total of workers }}\end{array}$ \\
\hline $\begin{array}{l}\text { Average schooling of } \\
\text { workers }\end{array}$ & RAIS a & $\begin{array}{c}\text { Study years: } \\
\text { total of study years } \\
\text { total of workers }\end{array}$ \\
\hline Innovative Labor & RAIS a & $\begin{array}{l}\text { Total of engineers, mathematicians, } \\
\text { physics, chemists, and R\&D professionals }\end{array}$ \\
\hline Number of contracts & RAIS a & Total of workers, blue and white collars \\
\hline Share & RAIS a & $\frac{\text { total of workers of firm }}{\text { total of workers of industry }}$ \\
\hline Number of patents & INPI ${ }^{b}$ & total of patent deposits at INPI \\
\hline Exports & SECEX c & Exports value in dollar of 2005 \\
\hline Imports & SECEX ${ }^{c}$ & Imports value in dollar of 2005 \\
\hline TFP & PIA $^{d}$ & $d Y-\left(\frac{d y}{d k}\right) d K-\left(\frac{d y}{d l}\right) d L$ \\
\hline
\end{tabular}

a - Annual Report of Social Indicators of Labor Department.

b - National Property Rights Institute.

c - External Trade Office.

d - Annual Industrial Report from Brazilian Institute of Geography and Statistics (IBGE). 


\section{REFERENCES}

Anatan, L. (2015). Conceptual issues in university to industry knowledge transfer Studies: a literature review. Procedia - Social and Behavioral Sciences, 211, 711-717.

Andersen, E. S., \& Lundvall, B. A. (1997). National innovation systems and the dynamics of the division of labor. In: C. Edquist, Systems of innovation: technologies, institutions, and organizations. (pp. 242-265). New York: Routledge.

Antonelli, C. (2003). The economics of innovation, new technologies and structural change. London: Routledge.

Audretsch, D. B. \& Lehmann, E. E. \& Warning, S. (2005). University spillovers and new firm location. Research Policy, 34 (7), 1113-1122.

Azagra-Caro, J. M., Barberá-Tomás, D., Edwards-Schachter, M., \& Tur, E. M. (2017). Dynamic interactions between university-industry knowledge transfer channels: a case study of the most highly cited academic patent. Research Policy, 46 (2), 463-474.

Bergebal-Mirabent, J., Garcia, J. L. S., \& Ribeiro-Soriano, D. E. (2015). University-industry partnerships for the provision of R\&D services. Journal of Business Research, 68 (7), 1407-1413.

Bercovitz, J., \& Feldman, M. (2006). Entrepreneurial universities and technology transfer: a conceptual framework for understanding knowledge-base economic development. Journal of Technology Transfer, 31 (1), 175-188.

Carlsson, B., \& Jacobsson, S. (1997). Diversity creation and technological systems: a technology policy perspective. In: C. Edquist, Systems of innovation: technologies, institutions, and organizations. (pp. 266-294). New York: Routledge.

Chang, S. H. (2017). The technology networks and development trends on university-industry collaborative patents. Technological Forecasting and Social Change, 118, 107-113.

Coleman, J. S. (1988). Social capital in the creation of human capital. The American Journal of Sociology, 94 - Supplement: Organizations and Institutions: sociological and economic approaches to the analysis of social structure, S95-S120.

Colombo, M. G., \& Delmastro, M. (2002). How effective are technology incubators? Evidence from Italy. Research Policy, 31 (7), 1103-1122.

Colyvas, J., Crow, M., Gelijns, A., Mazzoleni, R., Nelson, R. R., Rosenberg, N., \& Sampat, B. N. (2002). How do university inventions get into practice? Management Science, 48 (1), 61-72.

Cooke, P., Uranga, M. G., \& Etxebarria, G. (1997). Regional innovation system: institutional and organizational dimensions. Research Policy, 26 (4-5), 475-491. 
Dosi, G., Pavitt, K., \& Soete, L. (1990). The economics of technical change and international trade. London: Harvester Wheatshead.

Etzkowitz, H. (1998). The norms of entrepreneurial science: cognitive effects of the new university-industry linkages. Research Policy, 27 (8), 823-833.

Fernandes, G., Pinto, E. B., Araújo, M., Pontes, A. J., \& Machado, R. J. (2016). Perceptions of different stakeholders on managing collaborative university-industry R\&D funded contracts. Procedia Computer Sciences, 100, 878-887.

Franco, M., \& Haase, H. (2015). University-industry cooperation: researcher its motivation and interaction channels. Journal of Engineering and Technology Management, 36, 41-51.

Freitas, I. M. B., Marques, R. A., \& Silva, E. M. de P. (2013). University-industry collaboration and innovation in emergent and mature industries in new industrialized countries. Research Policy, 42 (2), 443-453.

Fuentes, C., \& Dutrenit, G. (2012). Best channels of academia-industry interactions for long-term benefit. Research Policy, 41 (9), 1666-1682.

Godin, G., \& Gingras, Y. (2000). The place of universities in the system of knowledge production. Research Policy, 29 (2), 273-278.

Knack, S., \& Keeffer, P. (1997). Does social capital have an economic payoff? A cross-country investigator. The Quarterly Journal of Economics, 112 (4), 1251-1288.

Lemos, D. C., \& Cario, S. A. F. (2017). Os sistemas nacional e regional de inovação e sua influência na interação universidade-empresa em Santa Catarina. Revista de Gestão, 24 (1), 45-57.

Maietta, O. W. (2015). Determinants of university-firm R\&D collaboration and its impact on innovation: a perspective from a low-tech industry. Research Policy, 44 (7), 1341-1359.

Malerba, F. (2002). Sectoral systems of innovation and production. Research Policy, 31 (2), 247-264.

Malik, T. H. (2013). National institutional differences and cross-border universityindustry. Research Policy, 42 (3), 776-787.

Motoyama, Y. (2014). Long-term collaboration between university and industry: a case study of nanotechnology development in Japan. Technology in Society, 36, 39-51.

Negri, F. (2006). Determinantes da capacidade de absorção das firmas brasileiras: qual a influência do perfil da mão-de-obra? In: J. A. Negri, \& F. Negri \& D. Coelho, Tecnologia, exportação e emprego (pp. 101-122). Brasília: IPEA.

Negri, J. A., \& Salerno, M. S. (2005). Inovações, padrões tecnológicos e desempenho das firmas industriais brasileiras. Brasília: IPEA.

Negri, J. A., \& Araújo, B. C. P. O. (2007). As empresas brasileiras e o comércio 
internacional. Brasília: IPEA.

Nelson, R. R., \& Rosenberg, N. (1993). Technical innovation and national systems. In: R. R. Nelson, National innovation systems: a comparative analysis (pp. 3-21). Oxford: Oxford University Press.

Nelson, R.R., \& Nelson, K. (2002). Technology, institutions, and innovation system. Research Policy, 31 (2), 265-272.

Panagopoulos, A. (2003). Understanding when universities and forms form RJVs: the importance of intellectual property protection. International Journal of Industrial Organization, 21 (9), 1411-1433.

Pavitt, K. (1984). Sectoral patterns of technical change: towards a taxonomy and a theory. Research Policy, 13 (6), 343-373.

Plewa, C., Korff, N., Johnson, C., Macpherson, G., Baaken, T., \& Rampersad, G. C. (2013). The evolution of university-industry linkages - a framework. Journal of Engineering and Technology Management, 30 (1), 21-44.

Putnam, R. (2001). Social capital: measurement and consequences. Paris: OECD.

Raudenbush, S. W., \& Bryk, A. S. (2002). Hierarchical linear models: application and data analysis methods. London: Sage.

Steingraber, R. (2009). Inovação e produtividade: o papel dos sistemas de inovação para a indústria brasileira (Tese de doutorado). Universidade Federal do Paraná, Curitiba.

Scandura, A. (2016). University-industry collaboration and firms' R\&D effort. Research Policy, 45 (9), 1907-1922.

Schot, J., \& Geels, F. W. (2007). Niches in evolutionary theories of technical change: a critical survey of the literature. Journal of Evolutionary Economy, 17 (5), 605-622.

Teece, D. J., Pisano, G., \& Shuen, A. (1997). Dynamic capabilities and strategic management. Strategic Management Journal, 18 (7), 509-533.

(C) 2017 por los autores; licencia otorgada a la revista Estudios económicos. Este artículo es de acceso abierto y distribuido bajo los términos y condiciones de una licencia Atribución-No Comercial 3.0 Unported (CC BY-NC 3.0) de Creative Commons. Para ver una copia de esta licencia, visite http://creativecommons.org/ licenses/by-nc/3.0/ 